\title{
Performance, serologic and tracheal responses of laying hens exposed to F strain of Mycoplasma gallisepticum
}

\author{
Desempenho, sorologia e respostas traqueias de galinhas poedeiras \\ expostas a cepa F de Mycoplasma gallisepticum
}

\author{
Leandro dos Santos Machado ${ }^{*}$, Dayse Lima da Costa Abreu', Mosar Lemos², Rogério Tortelly², \\ Jorge Couto Pimentel ${ }^{3}$, Luis Sesti ${ }^{3}$, Virginia Léo de Almeida Pereira', Elmiro Rosendo do Nascimento ${ }^{1}$
}

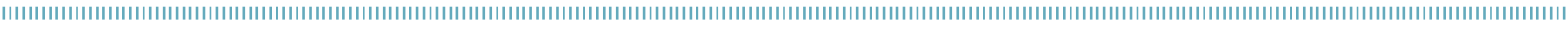

\begin{abstract}
The F strain of Mycoplasma gallisepticum (MG-F) protects chickens against mycoplasma infections, in which monitoring is made by serology and histopathology of trachea. This trial used 90 chickens, being 30 unvaccinated (G1 group), 30 eye-drop vaccinated at 8 weeks of age with MG-F (Ceva Animal Health, São Paulo, SP, Brazil) (G2), and 30 immunized at 8 and 11 weeks of age (G3). Samples were obtained from chickens on the $8,12,15,18,20$ and $24^{\text {th }}$ weeks of age for the enzymelinked immunosorbent assay (ELISA) test. Tracheal fragments were collected after necropsies on the 15 and $24^{\text {th }}$ weeks of age. Up to 12 weeks, the ELISA reactions in optical density (OD) were $0.165(\mathrm{G} 1), 0.151(\mathrm{G} 2)$ and $0.151(\mathrm{G} 3)$, all below 0.20 and with no significant difference among groups $(p>0.05)$. After the $15^{\text {th }}$ week, the ELISA reactions rose, yielding the following group averages by collecting dates: G1 $(0.18,0.19,0.18$, and $0.16), \mathrm{G} 2(0.36,0.49,0.47$, and 0.44$)$ and G3 $(0.41,0.52,0.59$, 0.60 ), being the means in G2 and G3 not significantly different between than, but significantly different from G1. The initial weight $(592.71,621.33$, and 594.40), the final weight $(1,932.58$, $1,987.59$, and $1,875.20$ ) and the weekly weight gain (11.65, 11.90 , and 11.14) were not significantly different among groups. At necropsy the gross tracheal score means by group and dates were: $15^{\text {th }}$ week $(0.25,0.61$, and 0.54$)$ and $24^{\text {th }}$ week $(0.54,0.58$, and 0.67$)$, being these difference not significantly ( $p>0.05)$. On microscopy, the tracheal score averages by groups G1, G2 and G3, respectively, were: $15^{\text {th }}$ week $(0.25,0.32$, and 0.47$)$ and $24^{\text {th }}$ week $(0.07,0.75$, and 0.08$)$. G2 yielded higher score average than G1 and G3 on the $24^{\text {th }}$ week. Higher tracheal changes for G2 and G3 as compared to G1 could be ascribed to MG-F infection. There were no evident prejudicial effects on live weight, weight gain and tissue changes by applying one or two vaccination doses.
\end{abstract}

KEYWORDS: Mycoplasma gallisepticum; layers; serology; body weight; histophatology.
RESUMO: A cepa F de Mycoplasma gallisepticum (MG-F) protege as galinhas de micoplasmose, e sua monitorização é feita por sorologia e histopatologia de traqueia. Este estudo utilizou 90 frangos, sendo 30 não vacinados (grupo G1); 30 vacinados via gota ocular a 8 semanas de idade com MG-F (Ceva Saúde Animal, São Paulo, SP, Brasil) (G2); e 30 imunizados em 8 e 11 semanas de idade (G3). As amostras foram obtidas nas $8^{\mathrm{a}}, 12^{\mathrm{a}}, 15^{\mathrm{a}}, 18^{\mathrm{a}}, 20^{\mathrm{a}}$ e $24^{\mathrm{a}}$ semanas para ensaio de imunoabsorção enzimática (ELISA). Fragmentos traqueais foram coletados após necropsias nas $15^{\mathrm{a}}$ e $24^{\mathrm{a}}$ semanas. Até a $12^{\text {a }}$ semana, as reaçôes de ELISA em densidade óptica (DO) foram 0,165 (G1), 0,151 (G2) e 0,151 (G3), todas abaixo de 0,20, e náo houve diferença significativa entre os grupos $(p>0,05)$. Após a $15^{\mathrm{a}}$ semana , a reação de ELISA subiu, produzindo as seguintes médias dos grupos por datas de coleta: G1 $(0,18,0,19,0,18$ e 0,16$), \mathrm{G} 2$ $(0,36,0,49,0,47$ e 0,44$)$ e G3 $(0,41,0,52,0,59,0,60)$, sendo as médias de G2 e G3 não significativamente diferentes entre si, mas significativamente diferentes da de G1. O peso inicial $(592,71$, $621,33,594,40)$, o peso final $(1.932,58,1.987,59,1.875,20)$ e o ganho de peso semanal $(11,65,11,90,11,14)$ não foram significativamente diferentes entre os grupos. $\mathrm{Na}$ necropsia, as médias do escore da macroscopia de traqueia por grupo e data foram: $15^{\mathrm{a}}$ semana $(0,25,0,61$ e 0,54$)$ e $24^{\mathrm{a}}$ semana $(0,54,0,58$ e 0,67$)$, e não se apresentou diferença significativa $(\mathrm{p}>0,05)$. Na microscopia, a média de escores de traqueia por grupos G1, G2 e G3, respectivamente, foram: $15^{\mathrm{a}}$ semana $(0,25,0,32$ e 0,47$)$ e $24^{\mathrm{a}}$ semana $(0,07,0,75$ e 0,08$)$. G2 apresentou maior média de escore do que G1 e G3 na 24a semana. Alteraçóes traqueais mais elevadas para $\mathrm{G} 2$ e G3 em relação a $\mathrm{G} 1$ poderiam ser atribuídas à vacinação por MG-F. Não houve efeitos prejudiciais evidentes no peso vivo nem no ganho de peso, tampouco alteraçóes teciduais na aplicação de uma ou duas doses de vacinação.

PALAVRAS-CHAVE: Mycoplasma gallisepticum; poedeiras; sorologia; peso corporal; histopatologia. 


\section{INTRODUCTION}

Mycoplasma gallisepticum (MG) causes coughing, sneezing, nasal and ocular discharge, decreased feed intake, growth retardation, ununiformity of eqq size and decrease in egg production and egg quality in laying hens. The growth retardation and ununiformity of layer hens in the first phases of development are two of the factors that determine the reproductive performance of laying hens as the rate of egg production and egg quality (NASCIMENTO; PEREIRA, 2009).

The epidemiological diagnosis of mycoplasmosis can be performed by serologic and etiological monitoring. The serum agglutination reaction (SAR) test, hemagglutination inhibition (HI) and enzyme-linked immunosorbent assay (ELISA) are well-known serology tools recommended by the governmental poultry health program (BRASIL, 2001). Although not a routine method, histopathology is used to aid in the evaluation of poultry response to MG infection. The grade of tracheal lesions is among the histopathological diagnostic methods used to evaluate the tissue response by MG infection (NUNOYA et al., 1987; PAPAZISI et al., 2002).

The damage caused by mycoplasma infections implies the adoption of control strategies. Vaccination in commercial laying hens reduces antibiotic therapy losses, increases egg production and minimizes the risk of new infections. The attenuated vaccines can stimulate cellular and humoral immune responses and act as an instrument of competitive exclusion in relation to field strains. Against MG, there are four live vaccines available: MG-F, MG-70, MG ts-11 and MG 6/85, which, in addition to reducing transovarial transmission, decrease the drop in egg production (NASCIMENTO; PEREIRA, 2009).

MG-F is widely used in vaccination programs in laying hens. The use of MG-F in infected chickens does not affect egg production as the field strains (CARPENTER et al., 1981), neither provoke decrease in body weight (BURNHAM et al., 2002; PEEBLES et al., 2007). Besides, MG-F displaces the field strains of MG, decreasing the number of them in the respiratory tract of vaccinated birds, keeping good transmissibility to the other birds, being a differential among ts-11 and 6/85 strains (LEY et al., 1997; LIU et al., 2013). However, the vaccine strain can induce airsacculitis and respiratory symptoms in chickens and turkeys (LIU; KLEVEN, 1982; ABD-EL-MOTELIB; KLEVEN, 1993).

The objective of this study was to evaluate serological, tissue and body weight gain in layers vaccinated with one or two doses of atenuated of MG-F strain, represented by MG-F vaccine (Ceva Saúde Animal, São Paulo, SP, Brasil).

\section{MATERIALS AND METHODS}

This experiment was conducted at a farm located in Cachoeiras de Macacu, Rio de Janeiro, Brazil, starting with 90 1-day-old chicks from specific pathogen-free (SPF) eggs hatched on site. During the experiment, the birds were housed in isolated experimental room units. The rooms measured $3 \times 3 \mathrm{~m}$, with brick wall, millimeter screen doors and Polyvinyl chloride (PVC) lining under the roof. Feed and water were provided ad libitum throughout the experimental period with tubular feeders and bell-shaped drinkers. The feed formulation followed the nutritional requirements of the chicken lineage and each stage of rearing. No artificial light supplementation was provided. The experiment was authorized by the permission number 155 from the Animal Care Ethic Committee of the Universidade Federal Fluminense, Niterói, RJ, Brazil.

\section{Experimental design}

A total of 90 leghorn chickens was used, being 30 birds per group. The experimental groups were: G1 (group 1: control not vaccinated hens); G2 (hens vaccinated at 8 weeks of age); and G3 (hens vaccinated at 8 and 11 weeks of age). G1 and G2 were vaccinated using attenuated MG-F strain (Ceva Saúde Animal, São Paulo, SP, Brasil) via ocular.

\section{Body weigh and ELISA serology}

The birds were weighed weekly from the 8 to the $24^{\text {th }}$ week. Blood samples were collected at $8,12,15,20,24^{\text {th }}$ for ELISA serology. ELISA was performed using M. gallisepticum Antibody Test Kit (Idexx Laboratories, SP, Brazil) according to manufacturer's specifications. The results obtained were considered positive when the optical densities (OD) were equal to or higher than 0.20 .

\section{Necropsy and histopathology}

At the 15 and $24^{\text {th }}$ weeks, the birds were euthanized by atlantooccipital disarticulation and necropsied for the extraction of trachea. The alterations found in the macroscopic examination were evaluated by scores of 0 to $4(0=$ normal, $1=$ hyperemia and petechiae, $2=$ excess mucus, $3=$ excess hemorrhage and mucus, and $4=$ hemorrhage, excess mucus and thickening). The tracheal fragments were fixed in $10 \%$ formaldehyde and processed by the usual paraffin inclusion techniques and stained by the hematoxylin-eosin method as described by BEHMER et al. (1976).

The microscopic analysis scores, used following the one described by NUNOYA et al. (1987), with minor modifications, were: $0=$ no alterations; $1=$ one to three discrete lymphoid aggregates (DLA) without submucosal invasion or with at least one of them invading submucosa, or four or more DLA, but without submucosal invasion; 2 = DLA (independently of submucosal number and invasion) associated with one or two lymphoid aggregate with follicular pattern (LAFP) without dispersion for the lamina propria; 3 = DLA (independently of submucosa number and invasion) associated with one or two LAFP with submucosal dispersion and/or discrete confluence between foci and/or 
follicles; 4 = DLA (independently of submucosal number and invasion) associated with three or more LAFPs with or without submucosal dispersion, and/or diffuse extensive infiltration of lamina propria (independently of invasion of the submucosa).

\section{RESULTS E DISCUSSION}

Serum samples collected at the $8^{\text {th }}$ week of age were negative for MG by ELISA, with the average OD of $0.163 ; 0.172$ and 0.174 for G1, G2 and G3, respectively.

There was no difference in OD between groups at the $12^{\text {th }}$ week of age (Kruskal-Wallis test, $p>0.05$ ). From the $15^{\text {th }}$ week onwards, differences in serological responses were detected. In G1, serum samples yielded negativity for MG up to 24 weeks of age. In G2 and G3 no differences were observed between ELISA OD means (Kruskal-Wallis test, $\mathrm{p}>0.05$ ), but serological responses were different among G1, G2 and G3 (KruskalWallis, Tukey-Kramer test, $\mathrm{p}<0.05)$. Vaccinated groups showed similar ELISA responses $(\mathrm{p}<0.05)$ regardless of the use of one or two doses of vaccine (Table 1$)$.

There was neither significant difference in weight nor in weekly weight gain in the three treatments (Table 2). These data demonstrated that both the handling and the side effect of the vaccine were not detrimental to the body's performance of the birds, corroborating with studies by BURNHAM et al. (2002), PEEBLES et al. (2007), VISCIONE et al. (2008) and VANCE et al. (2008). BURNHAM et al. (2002) and PEEBLES et al. (2007) did not find a negative effect on the body weight of birds inoculated with

Table 1. Serological responses by enzyme-linked immunosorbent assay (ELISA) optical density (OD) for MG-F in unvaccinated chickens (G1) and vaccinated with one dose at $8^{\text {th }}(G 2)$ and two doses at $8^{\text {th }}$ to $11^{\text {th }}$ week of age (G3) according to age in weeks.

\begin{tabular}{lcccc}
$\begin{array}{l}\text { Groups } \\
\text { (G) }\end{array}$ & $15^{\text {th**}}$ & $18^{\text {th**}}$ & $20^{\text {th } *}$ & $24^{\text {th }}$ \\
\hline 1 & $0.18 \pm 0.03^{\mathrm{a}}$ & $0.19 \pm 0.02^{\mathrm{a}}$ & $0.18 \pm 0.05^{\mathrm{a}}$ & $0.16 \pm 0.06^{\mathrm{a}}$ \\
\hline 2 & $0.36 \pm 0.11^{\mathrm{ab}}$ & $0.49 \pm 0.21^{\mathrm{ab}}$ & $0.47 \pm 0.20^{\mathrm{ab}}$ & $0.44 \pm 0.19^{\mathrm{ab}}$ \\
\hline 3 & $0.41 \pm 0.14^{\mathrm{b}}$ & $0.52 \pm 0.15^{\mathrm{b}}$ & $0.59 \pm 0.15^{\mathrm{b}}$ & $0.60 \pm 0.32^{\mathrm{b}}$ \\
\hline
\end{tabular}

*ANOVA/Kruskal-Wallis $p<0.05$; **ANOVA/Tukey-Kramer; $a$, b: different letters in the same column mean there is a significant difference.
MG-F in the pre-posture period. In relation to revaccination, VISCIONE et al. (2008) found no significant effect on body weight when comparing unvaccinated birds to vaccinated ones with $6 / 85$ at 10 weeks of age and vaccinated with $6 / 85$, followed by MG-F at 22 weeks of age nor vaccinated with 6/85, followed by MG-F vaccination at 45 weeks of age. VANCE et al. (2008) analyzing non-vaccinated birds, MG ts-11 vaccinated at 10 weeks of age and MG ts-11 vaccinated, followed by MG-F vaccination at 22-week-old or at 45-week-old, found the same results.

The averages of macroscopic and microscopic tissue reaction scores were obtained per studied group (Table 3). There was no significant difference between the means of macroscopic changes. Considering the means of the scores of the microscopic alterations, only a significant difference $(p=0.0068)$ was observed at the $24^{\text {th }}$ week of age. The group with one dose presented a mean higher at $24^{\text {th }}$ week $(0.75)$ compared to control $(0.07)$ and twice $(0.08)$ vaccinated groups. Probably the group vaccinated twice, by having been previously immunized, presented smaller tissue changes in relation to the group vaccinated once. It was also observed that birds yielded low scores throughout the experimental phase, which shows that MG-F does not cause significant tissue changes in the trachea. The present study is in agreement with the one by LEVISOHN et al. (1983), who observed birds inoculated with 14 days of age by intratracheal route and concluded that the colonization of MG-F in the trachea was accompanied by slight tissue changes. FERGUSON-NOEL et al. (2012) did not observe a significant difference between the vaccinated and non-vaccinated groups when evaluating the tracheal thickness at $15^{\text {th }}$ week in laying hens inoculated MG-F via aerosol at the $9^{\text {th }}$ week of age.
Table 3. Mean of macroscopic (M) and microscopic ( $\mathrm{m}$ ) lesion scores in unvaccinated $(G 1)$ hens and vaccinated with one dose at 8 week of age (G2) and two doses at $8^{\text {th }}$ to $11^{\text {th }}$ week of age (G3) in differents phases of the experiment.

\begin{tabular}{lcccc}
\multirow{2}{*}{ Vaccination } & \multicolumn{2}{c}{$15^{\text {th }}$ week } & \multicolumn{2}{c}{$24^{\text {th }}$ week } \\
\cline { 2 - 5 } Control & $\mathbf{M}$ & $\mathbf{m}$ & $\mathbf{M}$ & $\mathbf{m}$ \\
\hline MGF 1x & $0.25^{\mathrm{a}}$ & $0.25^{\mathrm{a}}$ & $0.54^{\mathrm{a}}$ & $0.07^{\mathrm{a}}$ \\
\hline MGF 2x & $0.61^{\mathrm{a}}$ & $0.32^{\mathrm{a}}$ & $0.58^{\mathrm{a}}$ & $0.75^{\mathrm{b}}$ \\
\hline
\end{tabular}

*ANOVA/Tukey; $p<0.05$; $a$, b: Different letters in the same column mean there is a significant difference.

Table 2. Initial weight, final weight and weekly weight gain (GG) of groups (G) of unvaccinated birds (G1) and vaccinated with one dose at week 8 (G2) and two doses at 8 to $11^{\text {th }}$ week of age (G3).

\begin{tabular}{|c|c|c|c|c|c|c|}
\hline & \multicolumn{2}{|l|}{ G 1} & \multicolumn{2}{|l|}{ G2 } & \multicolumn{2}{|l|}{ G3 } \\
\hline & $\mathbf{x}$ & SE & $\mathrm{X}$ & SE & $x$ & SE \\
\hline Initial weight $(g)^{1}$ & $592.71 \pm 165.62^{\mathrm{a}}$ & 29.75 & $621.33 \pm 82.87^{a}$ & 15.13 & $594.4 \pm 101.41^{a}$ & 20.28 \\
\hline Final weight $(\mathrm{g})^{1}$ & $1,932.58 \pm 398.88^{a}$ & 71.64 & $1,987.59 \pm 314.89^{a}$ & 58.47 & $1,875.2 \pm 274.06^{a}$ & 54.81 \\
\hline WWG $(g)^{2}$ & $11.65 \pm 2.69^{a}$ & 0.48 & $11.90 \pm 2.36^{a}$ & 0.44 & $11.14 \pm 1.89^{a}$ & 0.37 \\
\hline
\end{tabular}

'ANOVA/Kruskal-Wallis $p<0.05$; a, b: different letters in the same column mean there is a significant difference; ${ }^{2}$ ANOVA/Tukey-Kramer; WWG: weekly weight gain; $\mathrm{X}$ : average; SE: standart desviation. 


\section{CONCLUSION}

The serological response was not affected by revaccination with the MG-F strain, and both the use of one and two doses of vaccine did not have negative effect on body's performance of the birds. MG-F vaccination did not cause severe lesions in the trachea of SPF chickens under experimental conditions, and there were slight tissue changes after the first vaccination, which were not observed after the second vaccination.

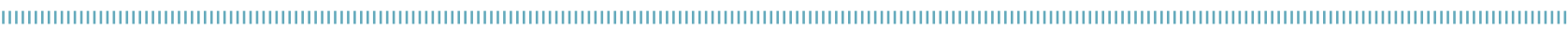

\section{REFERENCES}

ABD-EL-MOTELIB, T.Y.; KLEVEN, S.H. A Comparative Study of Mycoplasma gallisepticum Vaccines in Young Chickens. Avian Diseases, v.37, n.4, p.981-987, 1993.

BEHMER, O.A.; TOLOSA, E.M.C.; FREITAS NETO, A.G. Manual de técnicas para histologia normal e patológica. São Paulo: EDART, 1976. $241 \mathrm{p}$.

BRASIL. Ministério da Agricultura, Pecuária e Abastecimento. Normas Técnicas para o Controle e a Certificação de Núcleos e Estabelecimentos Avícolas para a Micoplasmose Aviária (Mycoplasma gallisepticum, synoviae e meleagridis). Diário Oficial da União, Seção 1, p.68, 24 ago. 2001.

BURNHAM, M.R.; PEEBLES, E.D.; BRANTON, S.L.; JONES, M.S.; GERARD, P.D.; MASLIN, W.R. Effects of F-strain Mycoplasma gallisepticum inoculation at twelve weeks of age on digestive and reproductive organ characteristics of commercial egg laying hens. Poultry Science, v.81, p.1884-1891, 2002.

CARPENTER, T.E.; MALLINSON, E.T.; MILLER, K.F.; GENTRY, R.F.; SCHWARTZ, L.D. Vaccination with F-strain Mycoplasma gallisepticum to reduce production losses in layer chickens. Avian Diseases, v.25, p.404-409, 1981.

FERGUSON-NOEL, N.; COOKSON, K.; LAIBINIS, V.A.; KLEVEN, S.H. The Efficacy of Three Commercial Mycoplasma gallisepticum Vaccines in Laying Hens Avian Diseases, v.56, n.2, p.272-275, 2012.

LEVISOHN, S.; YEGANA, Y.; HOD, I.; HERZ, A. A correlative in vivo study of the surface morphology and colonisation of the chicken trachea infected by Mycoplasma gallisepticum strains $\mathrm{R}$ and F. Avian Pathology, v. 12, p.247-261, 1983.

LEY, D.H.; MCLAREN, J.M.; MILES, A.M.; BARNES, H.J.; MILLER, S.H.; FRANZ, G. Transmissibility of live Mycoplasma gallisepticum vaccine strains ts-11 and 6/85 from vaccinated layer pullets to sentinel poultry. Avian Diseases, v.41, n.1, p.187-194, 1997.
LIU, J.J.; DING, L.; WEI, J.Z.; LI, Y. Influences of F-strain mycoplasma gallisepticum vaccine on productive and reproductive performance on commercial parent broiler chicken breeders on a multi-age farm. Poultry Science, v.92, p.1535-1542, 2013.

LIU, M.Y.; KLEVEN, S.H. Pathogenicity of two strains of Mycoplasma gallisepticum in turkeys. Avian Diseases, v.26, p.360-364, 1982.

NASCIMENTO, E.R.; PEREIRA, V.L.A. Micoplasmoses. In: DI FABIO, J.; ROSSINI, L.I. (Eds.). Doenças das Aves. Campinas: FACTA, 2009. p.485-500.

NUNOYA, T.; TAJIMA, M.; YAGIHASHI, T.; SANNAI, S. Evaluation of respiratory lesions in chickens induced by Mycoplasma gallisepticum. Journal of Veterinary Medical Science, v.49, p.621-629, 1987.

PAPAZISI, L.; SILBART, L.K.; FRASCA JR., S.; ROOD, D.; LIAO, X.; GLADD, M.; JAVED, M.A.; GEARY, S.J. A modified live Mycoplasma gallisepticum vaccine to protect chickens from respiratory disease. Vaccine, v.20, p.3709-3719, 2002.

PEEBLES, E.D.; BRANTON, S.L.; BURNHAM, M.R.; WHITMARSH, S.K., GERARD, P.D. Effects of supplemental dietary phytase and 25-hydroxycholecalciferol on the digestive and reproductive organ characteristics of commercial layers inoculated before or at the onset of lay with the F strain of Mycoplasma gallisepticum. Poultry Science, v.86, p.1805-1809, 2007.

VANCE, A.M.; BRANTON, S.L.; COLLIER, S.D.; GERARD, P.D.; PEEBLES, E.D. Effects of time-specific Fstrain Mycoplasma gallisepticum inoculation overlays on prelay ts 1 1-strain Mycoplasma gallisepticum inoculation on performance characteristics of commercial laying hens. Poultry Science, v.87, p.655-660, 2008.

VISCIONE, K.A.; BRANTON, S.L.; GERARD, P.D.; WHITMARSH, S.K.; PEEBLES, E.D. Effects of a prelay 6/85-strain Mycoplasma gallisepticum inoculation alone or in conjunction with subsequent F-strain M. gallisepticum inoculations during lay on the internal egg characteristics. Poultry Science, v.87, p.588-593, 2008. 